\title{
A narrativa machadiana: uma escrita em crise
}

\author{
Marilda de Souza Castro \\ Universidade Federal de Minas Gerais
}

\begin{abstract}
Texte de plaisir: celui qui contente, emplit, donne de l'euphorie; celui qui vient de la culture, ne rompt pas avec elle, est lié à une pratique confortable de la lecture. Texte de jouissance: celui qui met en état de perte, celui qui déconforte (peut-être jusqu'à un certain ennui), fait vaciller les assises historiques, culturelles, psychologiques, du lecteur, la consistance de ses goûts, de ses valeurs et de ses souvenirs, met en crise son rapport au langage. ${ }^{1}$
\end{abstract}

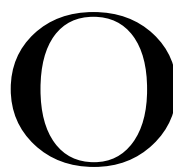

presente estudo objetiva apresentar uma leitura do conto "Uns braços" de Machado de Assis ${ }^{2}$ cuja narrativa anuncia a ficção sem lastro, a falta, a incompletude, os buracos na escrita, exigindo que o leitor reescreva o texto, a partir dos significantes, dos fragmentos e lacunas - restos que se configuram como pistas textuais em que ele busca equilibrar-se, no intuito de exercer sua função de agenciador, co-autor na construção dos inúmeros sentidos que proliferam no texto machadiano, sempre multiplicados, a cada leitura, na festa dos significantes que anunciam e enunciam uma realidade sígnica deslizante e avessa a interpretações definitivas.

Esclareço que a leitura ora realizada é feita à luz do pensamento de Roland Barthes, nos termos em que o teórico francês tece considerações sobre a força da literatura, na medida em que o escritor promove uma "trapaça

\footnotetext{
${ }^{1}$ BARTHES, 1973 , p. $25-26$.

2 MACHADO DE ASSIS, 1989, p. 33-41. Nas próximas citações de trechos do conto, objeto do presente estudo, indicarei, após a citação, apenas a página em que os mesmos se encontram.
} 
salutar" no interior da própria língua, promovendo em conseqüência "uma revolução permanente da linguagem", através "do trabalho de deslocamento que ele exerce sobre a língua". ${ }^{3}$

Nessa perspectiva, o que pretendo é perseguir a trajetória traçada por Machado, no referido conto, buscando flagrar a encenação, o exercício lúdico a que submete a própria língua, desafiando o leitor a ultrapassar a camada superficial do texto, a aparente ingenuidade da narrativa em si, e mergulhar nas asperezas de sua crítica mordaz e implacável aos mecanismos de dominação e interdição forjados pela sociedade burguesa.

O conto se inicia pela voz do narrador que anuncia a cena em que a personagem Inácio se surpreende com os gritos do solicitador Borges o qual se dirige a ele sob uma saraivada de impropérios, ao mesmo tempo que lhe entrega o prato de refeição.

Percebe-se, desde o início da narrativa, que os abalos da escrita machadiana já se insinuam, pois surpreende o leitor o fato de o momento da refeição - propiciador de gozo ${ }^{4}$ dos sentidos - vir acompanhado de um ingrediente tão inoportuno e desagradável como o xingamento, a repressão, o ato autoritário que constrange e revolta. A atitude de Inácio é mais surpreendente ainda, uma vez que, sem esboçar qualquer reação

\footnotetext{
${ }^{3}$ BARTHES. Aula, p. 16-17. Outros textos do autor serão também incorporados e citados no momento oportuno.

O diálogo entre a narrativa machadiana e o pensamento de Roland Barthes, apresentado no presente artigo, surgiu a partir dos estudos realizados em Seminário na UFMG, sob a Coordenação de Ana Clark Peres, no ano de 2002, do qual participei. No referido Seminário, tive oportunidade de aprofundar o estudo da obra desse polêmico teórico francês. E, à medida que ia relendo os vários textos de Barthes, escritos em épocas distintas, aumentava minha surpresa ante a riqueza e ousadia do pensamento barthesiano. Imediatamente também vislumbrei a possibilidade instigante de promover um diálogo entre o pensamento crítico de Roland Barthes e a narrativa de Machado de Assis. Dois autores cujos textos, provocativos e apaixonados, oferecem um desafio ao leitor que ousar mergulhar na leitura dos mesmos, também com paixão, e se dispuser a lê-los, "levantando a cabeça."

${ }^{4}$ Esclareço que, ao utilizar termos como gozo, desejo, inconsciente, sujeito, dentre outros, tomo-os na acepção atribuída a eles pelo senso comum, sem nenhuma intenção de relacioná-los ao viés psicanalítico.
} 
de revide ou revolta, recebe o prato e se põe a comer, silenciosamente, como se comer constituísse apenas uma necessidade fisiológica e não, principalmente, um momento de alegria dos sentidos em que a visão, o olfato e o paladar se manifestam em puras sensações sinestésicas. Há que mencionar também a correspondência imediata que se estabelece entre o comer e o copular; o desejo da refeição e o desejo da cópula. Leitura abonada pela insinuação, ao mesmo tempo velada e provocativa da cena ante o olhar do leitor.

Compelido a participar ativamente da trama narrativa, desestabilizado em seu conforto, o leitor se põe a vasculhar a teia textual, a fim de agenciar o processo da construção de sentido do texto, apropriando-se da sua condição de co-autor, figura autônoma, parceiro do próprio autor. Prisioneiro nas malhas do texto, ele se depara e se surpreende com a voz de Borges o qual, em discurso direto, continua a despejar outros impropérios sobre o pobre rapaz que se mantém silente.

Uma nova personagem é introduzida em cena, a quem Borges se dirige, também em discurso direto. Identificada como D. Severina, tratase da mulher que com ele vivia "maritalmente", informação anunciada pela voz do narrador. Também D. Severina não ousa confrontar-se com Borges. Sem manifestar-se verbalmente, apenas toca o pé do marido, no intuito de pôr termo àquela reação tão inoportuna do companheiro.

Nesse ponto, a narrativa sofre um corte, dentre inúmeros outros que vão atravessar todo o texto. O narrador novamente ocupa o primeiro plano e passa a retratar cada uma das três personagens que vão constituir a trama narrativa. Elas continuam à mesa, envolvidas com o momento da refeição. Entretanto o clima é de constrangimento, percebendo-se apenas "o tinir dos talheres e o ruído da mastigação." (p.34). De forma sutil e progressiva, instala-se um desconforto indefinido, provocando indagações de natureza múltipla que o leitor busca elucidar. Trata-se, pois, de um texto provocativo, cuja leitura exige um permanente levantar de cabeça, nos termos mencionados por Barthes, a fim de processar o surpreendente afluxo de idéias e riquezas polissêmicas. O texto machadiano exige uma "leitura, ao mesmo tempo irrespeitosa, pois que corta o texto, e apaixonada, pois que a ele volta e dele se nutre". 5

${ }^{5}$ BARTHES, 1988, p. 40. 
Ao invés de compelir o leitor, na busca de um sentido pré-inscrito no texto e anterior à leitura - o suposto sentido verdadeiro - desestabilizao em suas certezas e o insere no cerne mesmo da própria escritura, no rico processo leitura/escrita, em movimento permanente. Observa-se, sob esse aspecto, a incorporação de um "suplemento de sentido de que nem a gramática nem o dicionário podem dar conta." ${ }^{\circ}$

Nas rápidas pinceladas com que o narrador retrata Inácio, vai se configurando a imagem de um adolescente sonhador o qual, a mando do próprio pai, torna-se um auxiliar, um agente do contratador Borges. E, em meio à retratação das personagens, insere-se um componente espaçotemporal preciso que confere estatuto de validade à própria narrativa. A frase, breve e precisa, impõe-se como verdade irrefutável: "Passava-se isto na Rua da Lapa, em 1870." (p. 34)

A propósito da incorporação ao texto dessa informação tão precisa, em que se estabelece com rigor uma demarcação espaço-temporal, percebo a fina ironia machadiana: o olhar zombeteiro do narrador inspecciona a precisão dos dados exibidos, em atitude provocativa, desafiando o leitor a duvidar do relato apresentado. Naturalmente é possível perceber nesse dado a farpa machadiana, dirigida às tendências estéticas do realismonaturalismo, predominantes no século XIX, que exigiam rigorosa obediência às leis da verossimilhança, sendo uma das estratégias mais caras a localização precisa das cenas, em suas relações espaço-temporais, dentre outros procedimentos.

Retornando à caracterização de Inácio, sentado à mesa, no momento da refeição, o leitor flagra o estado de constrangimento em que ele se encontra, olhos fixos no prato, impossibilitado de dirigir o olhar ao objeto de seu desejo, ou seja, os braços de D. Severina que estavam sempre à mostra, tentando-o. Na seqüência de cenas, o olho do narrador se desloca e passa a focalizar a figura de D. Severina, destacada metonimicamente pelos braços que "eram belos e cheios." (p.34)

O exercício lúdico, a encenação da linguagem constitui traço vigoroso do estilo de Machado. Ao mesmo tempo que faz uma afirmativa, contrapõe um novo dado, num jogo permanente com o significante: afirma, corrige, complementa, de tal forma que o leitor tem de estar

${ }^{6}$ BARTHES, 1988, p. 40. 
sempre atento à caça dos sentidos que surgem em profusão no texto. Destaco um exemplo, dentre inúmeros outros, o qual me parece lapidar:

Não podia entender-se nem equilibrar-se, chegou a pensar em dizer tudo ao solicitador, e ele que mandasse embora o fedelho. Mas que era tudo? Aqui estacou: realmente, não havia mais que suposição, coincidência e possivelmente ilusão. Não, não, ilusão não era. E logo recolhia os indícios vagos, as atitudes do mocinho, o acanhamento, as distrações, para rejeitar a idéia de estar enganada.[...]

D. Severina compreendeu que não havia recear nenhum desacato, e concluiu que o melhor era não dizer nada ao solicitador; poupava-lhe um desgosto, e outro à pobre criança. Já se persuadia bem que ele era criança, e assentou de o tratar tão secamente como até ali, ou ainda mais. (p. 37)

A narrativa tem prosseguimento, ainda à mesa de refeição. Cessada a descompostura sem propósito, mesmo havendo terminado o jantar, Inácio permanecia sentado, alongando o café pós-refeição, com o único propósito de contemplar os braços de D. Severina, "ou porque sorrateiramente olhasse para eles, ou porque andasse com eles impressos na memória." (p.35)

Novamente arrancado por Borges de seus devaneios, o rapaz se levanta da mesa, indo refugiar-se em seu quarto, localizado nos fundos da casa. Nesse espaço íntimo, sentindo-se em liberdade, Inácio até se permite a ousadia de esboçar irritação e desespero. Em seguida, postase diante da janela, de onde podia avistar o mar. A visão do mar lhe proporcionava uma avaliação da própria vida, durante as cinco semanas em que estava em casa do Borges. Sentia vontade de ir embora, de voltar para junto da mãe e da irmã, mas, ao mesmo tempo, via-se acorrentado aos braços de D. Severina - "as suas tendas de repouso." (p. 35)

Deixando Inácio entregue a seus devaneios e fantasias, o narrador retorna à sala da casa e encontra a matrona, às voltas com suas descobertas e desconfianças. Também D. Severina é de súbito perturbada e interrompida por Borges que, intrometendo-se, sempre em tom de reprimenda, desloca-a de suas fantasias. Passado o momento inicial de sobressalto, feitos os esclarecimentos convenientes ao marido, este adormece e a deixa só na sala já escura, com a chegada da noite, entregue também aos seus devaneios e suposições.

A sós, D. Severina se vê dominada por reflexões que a levam a suspeitar de que era desejada por Inácio. Assustou-se com a suspeita que lhe acarretou uma vaga complicação moral. A retratação psicológica da personagem é deveras lapidar: considerada a suspeita de que o rapaz 
poderia estar interessado por ela, D. Severina a princípio, pressionada pela conduta moral imposta socialmente às senhoras casadas, analisa a hipótese de contar tudo ao Borges que certamente mandaria embora o garoto, encerrando-se a questão e proclamando-se a vitória da moral burguesa.

Todavia, como essa possibilidade de ser desejada pelo rapaz lhe agradava e até a envaidecia, tratou logo de encontrar uma desculpa, a fim de adiar a suposta denúncia. Decidiu averiguar melhor o comportamento do moço, evitando acusá-lo com precipitação. Passou a observá-lo com mais atenção, buscando flagrar um sinal, um vestígio, um indício qualquer. Concluiu, envaidecida, que era, ao mesmo tempo, amada e temida por Inácio. Um amor proibido, impedido de manifestar-se, interditado pelas normas morais da sociedade. A cena em que D. Severina se convence de que desperta desejo no rapaz e a complicação moral advinda dessa constatação leva a personagem a viver um conflito que ela tenta solucionar, segundo suas conveniências, procurando, ao mesmo tempo, administrar um possível sentimento de culpa. A ironia machadiana - sutil, mas implacável - já havia se insinuado desde a cena em que surgira a suspeita, na expressão colocada entre parênteses, como reflexão do narrador: "(Capciosa natureza!)" (p.37)

Julgo necessário deter-me mais demoradamente na análise da referida intromissão do narrador onisciente, com vistas a aprofundar a análise do texto, como leitora que busca, nas pistas e marcas deixadas na teia textual, os instrumentos necessários ao agenciamento do diálogo sempre dinâmico e enriquecedor entre autor/texto/leitor. Nesse sentido, percebo a insinuação irônica, marca permanente do estilo machadiano, que impregna os signos com seu olhar crítico e, em sua lucidez, disseca a personagem, na página em branco a qual se deixa sulcar pelo seu estilete mordaz, traçando uma radiografia do caráter da mesma. Nessa incisão cirúrgica, flagra a simulação, o jogo de máscaras, tudo girando em torno de algo velado, ou seja, os próprios interesses imediatos da personagem. Na verdade, constatase que ela não pretendia esclarecer a situação, com vistas a preservar a moral, os bons costumes sociais. Daí o comentário paralelo do narrador, a interrupção do fio narrativo, com a observação provocativa, referida anteriormente. O intrometimento do narrador, em comentário paralelo, constitui lâmina afiada, disseca a personagem, exibindo as mazelas inerentes à condição humana. Não deixa escapar nada, tudo flagra e captura, nas malhas da escrita, desafiando o leitor a penetrar nos meandros desse emaranhado de signos e participar da encenação, da teatralização oferecida pelo jogo dos significantes. 
Levando às últimas conseqüências sua vaidade narcísica de saberse desejada por Inácio, D. Severina simula a necessidade de averiguar suas suspeitas, procurando, ao mesmo tempo, coibir os possíveis efeitos das interdições sociais que poderiam prejudicar seus propósitos mais recônditos. O olho clínico do narrador se fixa no comportamento de D. Severina, flagrando o jogo de máscaras que então se encena. Na condição privilegiada de narrador onisciente, penetra nas regiões mais profundas do inconsciente de sua personagem, perscruta-lhe os sentimentos mais íntimos e os exibe ao leitor que é convocado, para, em co-parceria, deslindar a carga sêmica dos significantes, acordar a ambigüidade e os sentidos múltiplos que circulam no texto.

Após a descoberta feita, D. Severina muda a maneira de tratar o rapaz e esse novo comportamento dela perturba ainda mais Inácio, confundindo-o em relação a possíveis causas de uma mudança tão brusca. A insegurança do garoto apontava-lhe a partida, como única solução para o seu tormento. Todavia não tinha coragem de levar a termo suas considerações de ir embora e renunciar ao objeto de seu desejo.

No exercício lúdico dos signos, o narrador subitamente interfere e anuncia a partida de Inácio. Entretanto, no momento em que é anunciada a partida do rapaz, a mesma já havia ocorrido. Mais uma surpresa para o leitor que desliza de um significante a outro, no intuito de equilibrar-se na construção dos sentidos plausíveis, mas que estão sempre escapando. A frase que anuncia a partida é abrupta e fulminante: "Afinal, porém, teve de sair e para nunca mais; eis aqui como e por quê." (p. 37)

A narrativa sofre um deslocamento significativo: as cenas são narradas em retrospectiva. A perturbação de Inácio se acentuava, sem que ele próprio pudesse controlar-se ou entender-se. Só se sentia mais à vontade quando se refugiava em seu quarto e, junto à janela, olhando o mar, podia expandir suas fantasias. Em um domingo lindíssimo, "era um imenso domingo universal”(p.38), Inácio deitou-se na rede e adormeceu.

A essa altura da narrativa, a escritura machadiana atinge o ponto culminante: trapaceando os próprios limites da linguagem que, segundo Barthes, consistem na impossibilidade de "fazer coincidir uma ordem pluridimensional (o real) e uma ordem unidimensional (a linguagem)", Machado manifesta esse inconformismo do sujeito, com relação à falta de

${ }^{6}$ BARTHES. Aula, p. 22. 
paralelismo entre o real e a linguagem. Num jogo especular de desdobramentos, o autor de Dom Casmurro vai focalizar a cena ficcional cruzando-se com outra cena do sonho de Inácio, ou seja, promove a ficcionalização da própria ficção. Uma estratégia tão perturbadora que leva o leitor a duvidar de seus próprios mecanismos mentais que se mostram inteiramente abalados. Eis como se dá a superposição de planos narrativos, numa técnica surpreendente, através da aproximação gradativa entre o sonho de Inácio (ficcionalização da ficção) e o movimento de D. Severina, em direção ao quarto do garoto (ficcionalização no plano da narrativa).

A personagem se decide pelo sim, pela ida ao quarto do garoto e essa decisão já contém em si uma dimensão considerável de transgressão da lei, desestabilização da ordem social vigente. Transgressão ao mundo masculino, na tentativa de vencer a interdição ao prazer e proclamar o gozo dos sentidos. É um ato subversivo: uma senhora respeitável se decide ir ao quarto de um adolescente. Ousadia que se oculta sob a máscara da intenção filantrópica enunciada, intenção de desvelo e carinho maternal, mas que, na verdade, denuncia um ato do inconsciente. Sob esse aspecto observa-se a explicitação da força do desejo que se sobrepõe à razão. Trata-se de uma constatação recorrente em Machado, isto é, a explicitação da submissão ao desejo o qual vence a razão. É simplesmente magistral a seqüência de cenas que ocorrem após a tomada de decisão por parte de D. Severina . O narrador desnorteia o leitor, deixando-o sem nenhum eixo de apoio e equilíbrio, na medida em que vai narrando os fatos como se estivessem sendo captados por uma câmera cinematográfica, num frenético torvelinho de cortes e aproximação de planos, até a superposição final. Subverte a seqüência da própria narrativa, rompendo os limites da realidade ficcional que é superposta ao sonho de Inácio: o rapaz dorme e sonha com D. Severina e revela, em seu semblante, um ar de supremo gozo. D. Severina, por sua vez, estática diante do garoto, observa-o e imagina que, como sonhara com ele à noite, ele poderia estar sonhando com ela. A narrativa vai crescendo tanto com a utilização dessa técnica ilusionista que o leitor mesmo, em certas passagens, não sabe distinguir se a cena faz referência à seqüência narrativa em si, ou ao sonho de Inácio. Eis o trecho mais expressivo, transmitido pela voz do narrador onisciente:

Que não possamos ver os sonhos uns dos outros! D. Severina ter-seia visto a si mesma na imaginação do rapaz; ter-se-ia visto diante da rede, risonha e parada; depois inclinar-se, pegar-lhe nas mãos, levá-las ao peito, cruzando ali os braços, os famosos braços. Inácio, namorado 
deles, ainda assim ouvia as palavras dela, que eram lindas, cálidas, principalmente novas, - ou, pelo menos, pertenciam a algum idioma que ele não conhecia, posto que o entendesse. Duas, três e quatro vezes a figura esvaía-se, para tornar logo, vinda do mar ou de outra parte, entre gaivotas, ou atravessando o corredor, com toda a graça robusta de que era capaz. E, tornando, inclinava-se, pegava outra vez das mãos e cruzava ao peito os braços, até que, inclinando-se, ainda mais, muito mais, abrochou os lábios e deixou-lhe um beijo na boca.

Aqui o sonho coincidiu com a realidade, e as mesmas bocas uniramse na imaginação e fora dela. A diferença é que a visão não recuou, e a pessoa real tão depressa cumprira o gesto, como fugiu até a porta vexada e medrosa. (p.40)

Após a cena do beijo e a conseqüente perturbação de D. Severina, o conto se encerra de forma melancólica, com a instituição tácita da morte das ilusões. E o pacto efêmero do beijo não consegue proclamar o primado da emoção, rendendo-se, de forma definitiva, ao poder das convenções estabelecidas na sociedade: Inácio é mandado embora pelo solicitador, não porque Borges desconfiasse de alguma coisa, mas porque, sendo ele a lei, poderia dispor a seu bel prazer da vida do afilhado; D. Severina refugia-se em seu xale preto - metáfora do recato, da submissão e da culpa que ela estava disposta a acatar. Nem mesmo o desvario apaixonado dos amantes conseguiu triunfar sobre os preconceitos estabelecidos pelas instituições sociais. E o duo (ao contrário do que seria o comportamento normal entre os amantes) não ousou sequer revelar um ao outro o próprio sentimento amoroso que dominava a ambos. Optaram pela ocultação recíproca do segredo que os consumia. Final melancólico da narrativa em que paira um clima de desilusão, de trágico desencanto ante a existência que promove mais desencontros que encontros. Escrita que reflete uma concepção pessimista da vida e da condição humana. Texto impregnado de lucidez, provocando no leitor intensa inquietação e perplexidade.

$\mathrm{Na}$ caracterização das personagens, tanto Inácio quanto D. Severina exibem a marca viva do furo, da lacuna, do malogro, do avesso. E, na ânsia de preencher essa falta, suturar o vazio, ambos, em movimentos pulsionais, se buscam, mas se sabem impossíveis. Eles revelam a possibilidade ilusória do impossível desejo que sabe a sua falta.

Sob determinada ótica, pois, pode-se constatar que a narrativa de Machado é a narrativa da falta, do estilhaçamento, do furo. Nela as personagens são construídas, não sob o enfoque cartesiano que indaga e busca a verdade, o grande significado. Sua leitura permite ao leitor abordar 
o texto sob o enfoque que aponta para a falta, para o sujeito cindido que revela, pela palavra, sua incompletude.

Como narrador, Machado se posiciona em um distanciamento aparente, uma vez que se percebe em seus relatos uma escrita agressiva. Pratica a ironia na ordem narrativa, sutil, esgarçada, quase imperceptível ao leitor menos atento, mas de uma crueldade implacável, mordaz. Desconstrói a representação. Sua escrita desmascara a sociedade, exibindo, como troféu, todas as mazelas e lacunas que a constituem. Flagra o discurso do inconsciente, do desejo (o impulso) que pode ser perigoso para a sociedade porque a desestabiliza, transgride a ordem estabelecida, devendo, portanto, ser reprimido.

A escrita de Machado é sintomática, congruente com o discurso do inconsciente; é uma escrita da morte. Flagra a capitulação do sujeito ante os padrões dominantes. Suas personagens exibem sempre uma ferida, que não é tamponada, mas ao contrário, é exibida, através de uma ironia corrosiva. Machado realiza uma escrita de crise que aponta para a irrepresentabilidade.

A exemplo de textos da modernidade, a obra de Machado de Assis exige um leitor em parceria, que seja capaz de penetrar nos buracos, nas rendas do tecido-texto, não para preencher-lhe os vazios, mas para integrarse a eles, absorvê-los com o corpo. O leitor machadiano é compelido a ocupar um novo espaço na tecelagem da narrativa, no processo mesmo da enunciação. Sua participação ativa é essencial na exploração do corpus textual, seu papel é de criação e não de mero espectador (cuja função seria apenas de absorver um material lingüístico de significado fixado previamente). Machado instiga o leitor insistentemente, estimula e o desafia a exercitar suas habilidades mentais, a fim de participar criativamente desse embate que é o processo de leitura/escrita.

$\mathrm{E}$, a partir dessa nova concepção, ele está apto para mergulhar fundo e enfrentar o discurso irônico, dialógico e dialético do autor, marcado pelas violentas contradições que ferem a existência. Nesse mergulho deparase com um espaço onde circulam personagens destituídas da capacidade de decisão, subjugadas pelas forças impostas pelos padrões sociais.

No conto em tela, como em toda a obra do mestre Machado, o leitor é invocado insistentemente, sacudido de forma brutal, desafiado mesmo a abandonar a mediocridade do conforto burguês para defrontar-se com o drama da condição humana, as contingências sociais e inquietar-se, angustiar-se mesmo por não vislumbrar nenhuma possibilidade de 
salvação para a espécie humana. E, encarcerado no texto, perdido nessa floresta de signos, flagra a precária estabilidade dos significantes, os limites da própria linguagem.

Antes de concluir esse estudo, pretendo ainda tecer algumas considerações suplementares em relação à criação literária, ao processo da leitura e à força revolucionária da literatura. Observe-se o trecho:

A criação literária é um processo que tem dois pólos: o escritor e o leitor. A obra literária só existe, de fato e indefinidamente, enquanto recriada pela leitura, ofício que deve ser tão ativo quanto o do escritor. Nesse processo, o escritor é o desencadeador, mas não o dono absoluto, como certo romantismo remanescente quer fazer crer. No ato de recriação da obra pela leitura, a proposta inicial se amplia e as intenções primitivas do autor são superadas. Entre o dizer e o ouvir, entre o escrever e o ler, ocorrem coisas maiores do que os propósitos de um emissor e as expectativas de um receptor: há um saber inconsciente circulando na linguagem, instituição e bem comum de autores e leitores.

O que importa, assim, não são as intenções mensageiras do autor (por melhores que sejam), e sim sua capacidade de imprimir à obra aquele impulso poderoso e aquela abertura estimulante que convide o leitor a prosseguir sua criação. ${ }^{8}$

A meu ver, a obra do autor de Quincas Borba convida e estimula o leitor a completar sua criação, ou mesmo ultrapassá-la. Assim, no conto abordado, constatada a tragicidade do mundo burguês que destrói todas as chances de realização do sujeito, inviabilizando mesmo seu projeto amoroso, via interdição, ditada pelos discutíveis padrões da moral burguesa, o leitor, revolvendo a teia textual, investigando-lhe as lacunas, os entre ditos e os não ditos, pode preencher esse vazio, pode propor outro desfecho ao texto, lendo-o para além do seu final, transgredindo-o, numa ultrapassagem que sinaliza para o inconformismo com o mundo, para a afirmação de que "as coisas poderiam ter sido outras, poderão ser outras. A função revolucionária da literatura não consiste em emitir mensagens revolucionárias, mas em levantar, por suas reordenações e invenções, uma dúvida radical sobre a fatalidade do real, sobre o determinismo da história" que não passa de mera construção discursiva, sendo, portanto, passível de alteração.

\footnotetext{
${ }^{8}$ PERRONE-MOISÉS, 1990, p. 108-109.

9 PERRONE-MOISÉS, 1990, p. 108.
} 


\section{Referências Bibliográficas}

BARTHES, Roland. Le plaisir du texte. Paris: Seuil, 1973.

BARTHES, Roland. Escritores e escreventes. In: BARTHES, Roland. Ensaios críticos. Trad. Antônio Massano e Isabel Pascoal. Lisboa: Edições 70, 1977. p. 205-215.

BARTHES, Roland. O rumor da lingua. Trad. Mário Laranjeira. São Paulo: Brasiliense, 1988.

BARTHES, Roland. O prazer do texto. Trad. J. Guinsburg. 5. ed. São Paulo: Perspectiva, 1999.

BARTHES, Roland. Aula. Trad. Leyla Perrone-Moisés. 9. ed. São Paulo: Cultrix, $19 .$.

CULLER, Jonathan. As idéias de Barthes. Trad. Adail Ubirajara Sobral. São Paulo: Cultrix/EDUSP, 1988.

MACHADO DE ASSIS. Várias histórias. Rio de Janeiro: Garnier, 1989. p. 33-41.

PERES, Ana Maria Clark. O infantil na literatura-uma questão de estilo. Belo Horizonte: Miguilim, 1999.

PERES, Ana Maria Clark. Revisitando o estilo: por uma travessia na escrita? Belo Horizonte: FALE/UFMG, 2001.

PERRONE-MOISÉS, Leyla. Flores da escrivaninha-ensaios. São Paulo: Companhia das letras, 1990.

ROMERO, Sílvio. Machado de Assis - estudo comparativo de literatura brasileira. Campinas: Editora da UNICAMP, 1992.

SCHWARZ, Roberto. Ao vencedor as batatas: forma literária e processo social nos inícios do romance brasileiro. São Paulo: Duas cidades, 1977.

SILVIANO BRANDÃO, Ruth. Literatura e psicanálise. Porto Alegre: Editora da Universidade, 1996. 


\section{Resumo}

O presente artigo se propõe a fazer uma leitura do conto Uns braços de Machado de Assis, apontando nele alguns traços marcantes do estilo machadiano. Nesse sentido, pretendo estabelecer um diálogo entre aspectos do pensamento de Roland Barthes e a escrita de Machado. Destaco, no referido conto, sobretudo o traço do furo, da falta, da incompletude, do logro - marca persistente da narrativa machadiana que desconforta o leitor, colocando-o em estado de crise, na sua relação com a linguagem. A meu ver, o texto do autor de Dom Casmurro, caracterizaria le texte de jouissance, nos termos propostos por Barthes. Nesse sentido tecerei considerações sobre a linguagem literária e o exercício de deslocamento produzido pelo escritor, no cerne da própria língua, promovendo, segundo Barthes uma trapaça salutar. Ainda me disponho a desenvolver, ao longo do estudo, reflexões acerca da importância da literatura, como força revolucinária que consiste em levantar questões sobre a própria realidade a qual não passa de construção discursiva e, portanto, é passível de ser modificada.

\section{Résumé}

Cet étude se propose à faire une lecture sur le texte Uns braços de Machado de Assis . On fera des considérations sur des traits rémarquables du style machadien qui se caractérize pour une narrative de la manque, de l'incomplétude. Une narrative qui provoque de l'angoisse au lecteur. Pourtant, un "texte de jouissance: celui qui met en état de perte, celui qui déconforte (peut-être jusqu' à un certain ennui)". On réflechira bien aussi sur le texte littéraire et l'exercice de déplacement introduit pour l'écrivain à l'intérieur même du langage, y faisant, selon la pensée de Barthes, un tourbillonemment salutaire; on réflechira, finalement sur des traits de la littérature comme une force révolutionnaire qui pose des questions sur la propre réalité qui n'est que des constructions de langage et, pourtant, elle peut être modifiée. 